HAWAII AGRICULTURAL EXPERIMENT STATION, JARED G. SMith, Special Agent in Charge.

\title{
THE ECONOMIC SEAWEEDS OF HAWAII AND THEIR FOOD VALUE.
}

\author{
BY \\ MINNIE REED, M. S., \\ Science Teacher Kamehameha Manual Training Schools, \\ Honolulu, Hawait.
}

[Reprint from the Annual Report of the Hawaii Agricultural Experiment Station for 1906.] 


\section{CONTENTS.}

Page.

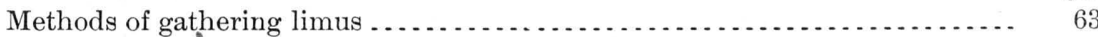

Native methods of preparing and serving limus for food . . . . . . . . . . 65

The most popular varieties of limus . . . . . . . . . . . . . . . . . . . . . . . 70

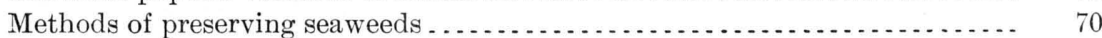

The limus most abundant and easily gathered . . . . . . . . . . . . . . . . . . 71

Native methods of cultivating limus ... . . . . . . . . . . . . . . . . . . 73

Value and amount of native seaweeds sold in Honolulu . . . . . . . . . . . . . . . 74

Value of seaweeds imported by Orientals into Hawaii . . . . . . . . . . . 75

Use of limus for medicine and incantations. . . . . . . . . . . . . . . . . . 76

Chemical analyses and comparative food values of seaweeds. . . . . . . . . . $\quad 77$

Amount of gelatin or glue found in Hawaiian algæ. . . . . . . . . . . . . . . . 79

Hawaiian limus for making agar-agar for culture media . . . . . . . . . . . . . . 80

Further utilization of Hawaiian seaweeds for food, gelatin, farina, glue, and

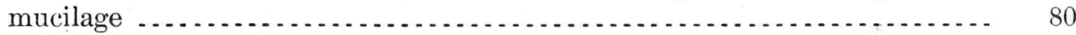

Methods of preparing jellies, blancmange, soups, etc . . . . . . . . . 82

Comparison of Hawaiian and Japanese species of economic algæ. . . . . . . . . 82

Possibility of cultivating native, Japanese, Java, or Ceylon algæ in favorable localities on the Hawaiian or American coast. . . . . . . . . . . . . . . . . . 84

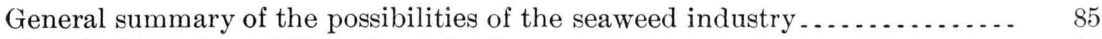

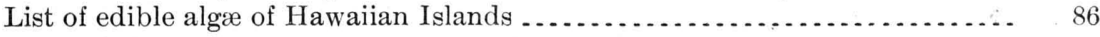




\section{ILLUSTRATIONS.}

Plate IV. Fig. 1.-Using glass-bottomed box to search for limu. Fig. 2.-

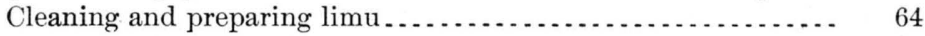

V. Limu kohu, Asparagopsis sanfordiana ..................... $\quad 70$

VI. Fig. 1.-Limu manauea, Gracilaria coronopifolia. Fig. 2.-Limu huna, Hypnea sp .................................... $\quad 70$

VII. Fig. 1.-Limu pakaeleawaa, Grateloupia filicina. Fig. 2.-Limu akiaki, Ahnfeldtia concinna ..............................

IV 


\title{
THE ECONOMIC SEAWEEDS OF HAWAII AND THEIR FOOD VALUE.
}

\author{
By Minnie Reed, M. S.,
} Science Teacher, Kam̌ehameha Manual Training Schools, Honolulu, Hawaii.

Hawaii has nearly a thousand miles of coast line; as a consequence the native Hawaiians are skillful and daring fishermen and sailors, as well as splendid swimmers. The Hawaiians, like the Japanese, are fond of almost all the products of the sea, and, like them, prize the seaweed very highly for food. Ancient Hawaiians probably seldom ate a meal without some kind of $\operatorname{limu}^{a}$ or seaweed, and even to-day no Hawaiian feast is considered quite complete without several varieties served as a relish with meats or poi. ${ }^{b}$

Many tons of these seaweeds are gathered and eaten by the Hawaiians annually, besides large quantities are imported from the Orient and San Francisco for the consumption of both the Japanese and Chinese. The seaweed sold in Honolulu alone amounts annually to thousands of dollars.

Before the coming of the white man to these islands the diet of the poorer Hawaiians was largely poi, fish, and limu. Even poi was scarce in times of war or famine, and then the poorer fishermen contented themselves with only fish and limu. Sometimes for weeks no other vegetable food could be obtained but limu, which can be gathered all the year, except during very severe storms. Sweet potatoes, taro, and bananas could only be grown in the good soil, where there was plenty of rain or sufficient water for irrigation. Many of the fishing. villages had no fertile land near them, so these people were compelled to go to the mountain valleys to secure all their food except what they fished from the sea. Until the death of Kamehameha the Great (1819) women suffered the death penalty if they ate bananas, cocoanuts, turtles, pork, or certain fish, so that their diet was even more limited than that of the men. They must have suffered greatly during times of famine and war, when their only food came from the

$a$ Limu is the Hawaiian name generally applied to all water plants, and is equivalent to our word algæ. They sometimes include various pond weeds, or fresh-water limu, as nitella, chara, etc. Usually limu means either fresh or salt water algæ that are edible.

$b$ Poi is a thick paste made from the root of the taro plant (Colocasia esculentum), and takes the place of rice or bread in the native diet. It is made by pounding the moistened boiled or steamed roots with water to smooth paste, which is then slightly fermented. 
sea. Before the coming of the missionaries there were no fruits except bananas, cocoanuts, and the mountain apple, and none of these were ever abundant, except the mountain apple or 'ohia, ${ }^{a}$ which is plentiful only during July and August in the mountain valleys wherever there is a heavy rainfall.

It was because of this limited food supply, no doubt, that the early Hawaiians learned to use for food almost every living thing, both plant and animal, found along their coasts. Almost every kind of seaweed that could possibly be eaten was used for food by some Hawaiians, while certain of the more attractive algæ were universally used wherever and whenever it was possible to secure them from the sea. The people living in the mountain valleys used, in addition to marine algæ, several kinds of the soft green fresh-water algæ from the streams and ponds. Nothing edible, from tiny shellfish or minnows an inch long to great sharks, escaped the hungry Hawaiian fisherman. Likewise he gathered seaweeds, large and small, and also the fine green algæ of the fresh water to satisfy his hunger for vegetable food. The limu had to take the place of all green vegetables - as onions, lettuce, beets, beans, peas, etc. - as well as fruits, and must have helped very much to vary the monotony of a diet of fish and poi, which were then as now the two staple foods of the native Hawaiians.

There are over seventy distinct species of algæ or limu used for food by the Hawaiians. Of these seventy species not more than forty are in general use. The other thirty or thirty-five are used only by a few people in certain small areas where they are found in limited quantities. There are perhaps a dozen or more common species of algæ, mostly marine, that are termed by the Hawaiians simply limu, or with some descriptive appellation, like limu make, meaning poisonous limu. Each edible limu has its own special appellation besides the generic name limu with which it is combined either as a descriptive adjective or as a suffix.

The following notes and observations have been collected during the last three years from various sources, and from personal study in the markets and along the beaches wherever the limu gatherers were at work collecting or preparing algæ for food. In addition to this, much information has been secured from Hawaiian friends who have very kindly assisted the writer in various ways in collecting both the specimens and data. The writer is especially indebted to Mrs. Emma Metcalfe Nakuina, Mrs. W. L. Bowers, Mrs. Elizabeth Kahanu Gittle, Mrs. Rosina Shaw Leslie, Mrs. Kepoikai, Mr. B. K. Kaiwiaea, Mrs. Deverel, Judge Kahele, and many others for the native names, specimens for study, and descriptions of the methods of preparing them

a Eugenia malaccensis, in the valleys and mountain slopes in the lowest forest zone. Fruit sweetish, juicy, about size of early June apple, and resembling a red apple, except in flavor. 
for food. A number of the pupils of the Kamehameha schools from different islands have, with the aid of their relatives, helped secure specimens of their edible algæ with the native names. They have also furnished many notes on the preparation and preservation of algæ for food. The writer is also very greatly indebted to Dr. W. A. Setchell, of the University of California, for identifying and verifying many specimens, and to R. A. Duncan, food commissioner and chemist of the Territory of Hawaii, for analyzing the edible algæ and for the use of his library.

The following publications have been consulted for tables of analyses and other data: U. S. Dept. Agr., Office of Experiment Stations Circular 46 (rev.), by C. F. Langworthy, Ph. D.; Office of Experiment Stations Bulletins 68, 107, and 159; United States Dispensatory; Analyses of Taro and Poi, report of Dr. E. C. Shorey when food commissioner and chemist of the Territory of Hawaii; Postelsia, the Yearbook of Minnesota Seaside Station, 1901; and Seaweed Industries of Japan and the Utilization of Seaweeds in the United States, by Hugh M. Smith. Bul. [U. S.] Bureau of Fisheries, 24 (1904).

\section{METHODS OF GATHERING LIMIUS.}

Most of the limu is gathered by native women and children, except that which grows in the deeper or rougher water, far out on the coral reefs, or on exposid rocks, where expert swimming and more strength are required, and also where a boat is usually needed. In such places at least two people are required, and often a party of three or more men and women go together. The women usually gather the limu while the men are fishing and caring for the boat and nets.

The limu gatherers go out at low tide with tin pails, old sacks, and pieces of sharpened iron or an old knife, and scrape the seaweed from the coral or rocks. The seaweed is freed from sand and pebbles and each kind placed in a separate receptacle, if possible. If the limu grows nearer shore in the sand or mud, or floats in near the beach, the women and children wade out, gathering it without any implements, carefully washing out the sand, mud, or small sea animals, and pulling out all inedible limu before placing it in their pails or sacks. They often wade out into the water above the waist, following the tide as it recedes. A few varieties of limu drift ashore, and are simply gathered along the water's edge from the rocks and sand and shaken free from the sand or inedible weeds. The following varieties are often found drifted on the sand or rocks: Limu huna (Hypnea nidifica), limu manauea (Gracilaria coronopifolia), limu kala (Sargassum echinocarpum and S.cymosum), and limu lipeepee or limu maneoneo (Laurencia papillosa, L. pinnatifida, L. virgata, L. obtusata, and a few other species of Laurencia not yet identified). 
Limu uaualoli (Gymnogongrus vermicularis var. americana and $G$. diciplinalis), limu kohu (Asparagopsis sanfordiana), limu aalaula (Codium muelleri and C. tomentosum), limu lipoa (Dictyota acutiloba var. distorta and Haliseris plagiogramma), and limu lipeepee of several varieties grow far out on the coral reefs or on exposed rocks in the surf. These all have rather tough, firm holdfasts, and a stout sharp knife or chisel is required to loosen them from their supports and strong swimmers to gather them. Those named above are usually gathered by a party in a boat, though sometimes the limu gatherers venture far out on the shallow coral reefs with only their pails or bags and their chisels.

The following varieties of limu grow quite near the tide line along shore, but on exposed black lava rocks in rough water: Limu akiaki (Ahnfeldtia concinna), limu loloa (Gelidium capillacea, G. corneum, G. filicinum (?), G. pulvinatum (?), G. latifolium (?), G. attenuatum (?), and Pterocladia capillacea), limu uaualoli (Gymnogongrus disciplinalis), and limu luau (Porphyra leucosticta). These all have very tenacious holdfasts, so generally require a strong, skillful swimmer with a knife or chisel to gather them in large quantities.

Those growing near shore in quiet waters in sand or mud or on small stones are easily gathered with only the bare hands, and usually the older women and children gather these varieties, while the men and the younger strong women gather the varieties growing in the rougher or deeper water. The following are the varieties easily gathered near shore: Limu eleele ${ }^{a}$ (Enteromorpha prolifera, E. linaa, E. intestinalis, E. prolifera var. tubulosa, and E. plumosa), limu huna (Hypnea nidifica), limu manauea (Gracilaria coronopifolia), limu pakaeleawaa or limu huluhuluwaena ${ }^{b}$ (Grateloupia filicina), limu huluilio (Chætomorpha antennina, Ectocarpus sp. (?), Centroceras clavulatum, and Stigeoclonium amoenum), limu pahapaha ${ }^{c}$ (Ulva fasciata and $U$. lactuca var. rigida), limu oolu (Chondria tenuissima var. intermedia), and limu puaki (Liagora decussata). There are besides a few other species found only in small quantities, or in certain localities, and only eaten by the Hawaiians in remote districts, or by a small group of families who alone seem to appreciate their flavor. Limu luau (Porphyra leucosticta) is one of these which appears in winter or spring after heavy

$a$ Limu eleele is applied to a number of slender thread-like green algæ growing near the mouths of streams in brackish water. Most of them are Enteromorphas. On Maui the edible Enteromorphas are called by some natives limu pipilani.

$b$ Limu huluhuluwaena is the native name for Grateloupia filicina, generally used on the island of Hawaii and in frequent use on Maui and Oahu, while limu pakaeleawa is the name always used on Kauai and in common use on Molokai, Maui, and Oahu.

${ }^{c}$ Limu pahapaha is applied to several Ulvas on Oahu, Molokai, Maui, and Kauai, while limu pakaiea is the name for the same Ulva on Hawaii. 

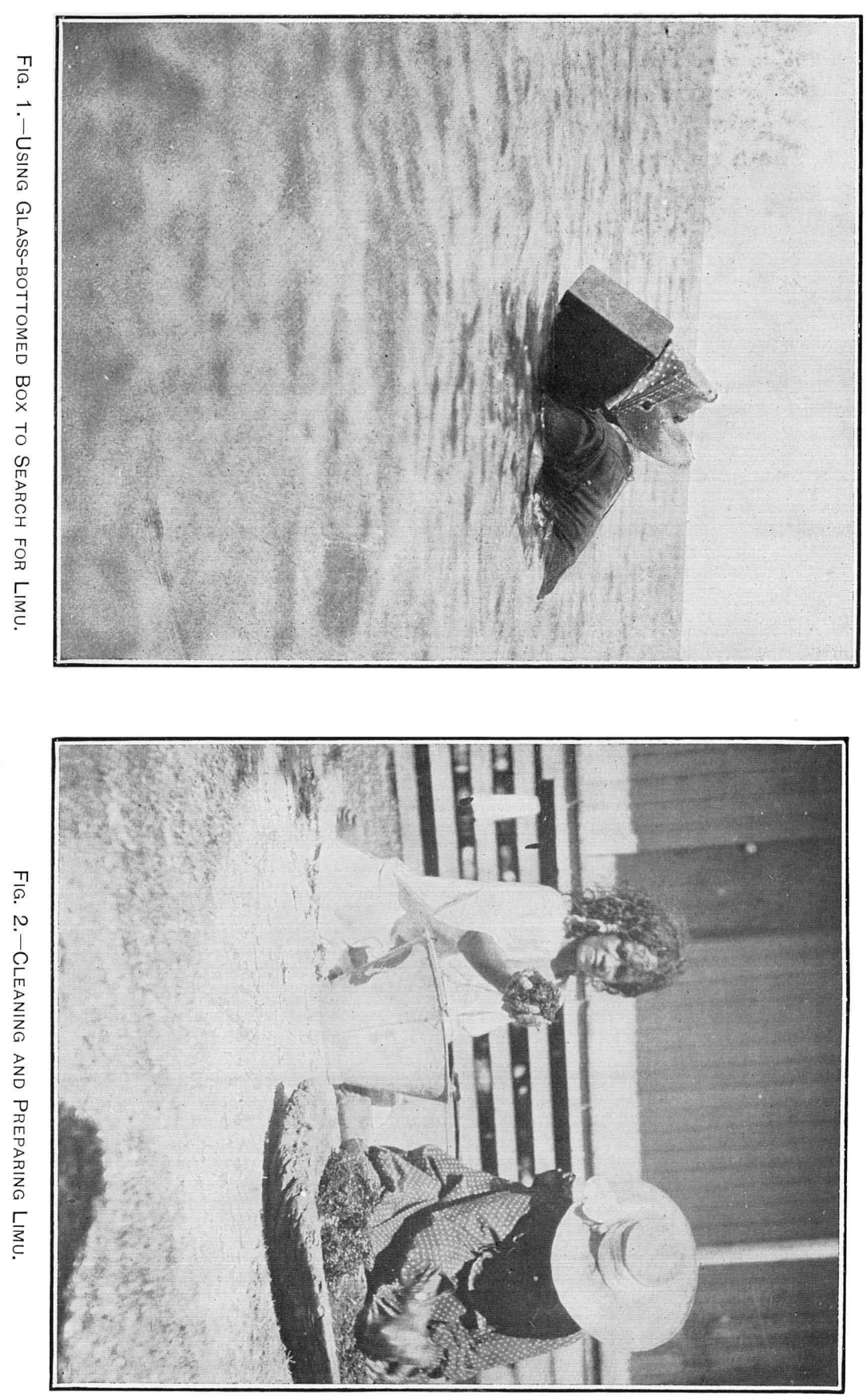
storms and last for only a few days. It is found on bold exposed rock constantly dashed by waves, so it is difficult and dangerous to collect it, especially as it is extremely slippery and has to be scraped forcibly from the rocks in small bunches while the collector clings to his support and avoids the heavy waves. He must be sure-footed, quick, and a strong swimmer, if he collect limu luau. Limu eleele must always be floated or dipped out of the water into pails, because it always grows at the mouth of streams in the quiet brackish water, so is full of silt or sand. This is partly washed out as the limu is scraped or floated out with the hands into the pails. This limu is very fine and slippery, like hair, so it must be handled in a different manner from other algæ, and requires much more care to remove the sand, the small, clinging mollusks, and crustaceans.

Occasionally you will see a limu gatherer out on the reef, in water almost to her waist, looking very intently through a square glassbottomed box, and now and then probing the depths with a sharpened iron rod. The iron rod is used to loosen certain mollusks, limu uaualoli, limu lipoa, limu maneoneo, and also to kill eels and octopi, all of which are highly prized for food. The boxes or square frames with a glass bottom have been recently introduced by the Italian fishermen, and are not in general use even near Honolulu. In Plate IV, figure 1, will be seen a limu gatherer looking through the glass box, probing with the iron bar, with a large bag suspended from her neck, into which she thrusts her limu, mollusks, or squid. ${ }^{a}$

At low tides, when the water recedes, wherever there are flats or shallow coral reefs and quiet water, one can see many natives with bags and old knives wading far out gathering limu and other sea edibles, as mollusks, squid, sea urchins, and sea cucumbers or bêche de mer.

\section{NATIVE METHODS OF PREPARING AND SERVING LIMUS FOR FOOD.}

Immediately after gathering the limu it is very carefully washed, either in salt or fresh water, to remove all sand, mud, or clinging mollusks and crustaceans. The Hawaiian women are most particular about this cleaning process, so wash the seaweed through many waters, and look it over very carefully to remove every particle of grit or inedible limu that often becomes entangled with the edible varieties. (See limu cleaning in Plate IV, figure 2.)

A few varieties of limu can not be washed in fresh water without injuring the flavor and causing a very rapid decay, so that in a few hours it is entirely unfit for food. The following are the very perishable varieties that must be cleaned in salt watẹr and eaten soon after

$a$ The term "squid" is universally applied to the common octopus, Octopus octopodia. 
preparation: Limu oolu, limu lipeepee, limu lepeahina (Halymenia formosa), limu moopuna-ka-lipoa (Grifithsia sp.?), and probably a few others not in general use.

After cleaning, the seaweed is always salted and usually broken, pounded, or chopped into small pieces, and usually it is eaten uncooked as a relish with poi, meats, or fish. Raw fish is never eaten without limu or some other relish, such as raw tomatoes, chili peppers, or onions.

The Hawaiians in the ancient times seldom cooked their limu, though it was occasionally placed in the imu or earthen pit with pig or dog and roasted or steamed. This was done when there was a famine or war and taro and sweet potatoes were scarce. Limu akiaki, limu huna, limu manauea, and limu uaualoli were all sometimes cooked in this way as a substitute for taro and sweet potatoes.

The Hawaiians of to-day do far more cooking than formerly, because they are not hampered for cooking utensils as their ancestors, who had no vessels that could be set over the fire. Water could only be heated by putting in hot stones, and boiling or stewing was almost impossible. Their only method of cooking meats or fish was in the primitive imu, or pit lined with stones and heated with a big fire. This when well heated was lined with banana and $\mathrm{ti}^{a}$ leaves, then pigs, dogs, fish, taro, or sweet potatoes were placed on the ti leaves, covered well with ti and banana leaves, while over this was heaped earth. This was allowed to steam twelve hours or more before serving. Usually hot stones were placed in the pig to hurry the cooking, or if the pig was large it was cut into small pieces for each individual. These small pieces with a roll of taro leaves or some gelatinous limu were placed in ti leaves and tied in bundles, which were placed in the pit and roasted as described above. The limu when steamed in this way with meats becomes gelatinous and is flavored with the meat juices. It is considered very delicious by the natives, who always eat it with the roasted meat and sweet potatoes.

Very few poor Hawaiians have stoves or ovens, so that all their baking or roasting is still done in the primitive way. Their cooking is done over a fire in an old coal-oil tin out of doors, hence must be very simple. Meat is usually boiled or stewed in small quantities with taro leaves or limu. Whenever any Hawaiian gives a large dinner the pig and fish are roasted in the imu as in olden days. The following limus are often cooked with boiled meats or put into soups or gravies for thickening and flavoring, as well as with roast pig in the imu: Limu akiaki, limu uaualoli, limu loloa, limu lipeepee, limu

a Cordyline terminalis, found on the mountain sides on the edges of the forest. The leaves are used instead of paper for wrappers for food, and for plates, etc. The root is roasted and eaten and is also fermented into a kind of strong drink like rum. 
kohu, limu lipoa, limu eleele, limu pahapaha, limu huna, limu manauea, limu aalaula, and limu kala. The tougher, more cartilaginous ones are boiled long enough for the gelatin to be softened or dissolved, as limu akiaki, limu huna, limu manauea, limu uaualoli, limu loloa, and limu lipeepee, while the others are only dropped into the hot soup or gravy just as it is about to be served.

Limu huna is especially prized for boiling with squid or octopus, though limu manauea and limu akiaki are often used as substitutes. These limus, when boiled with squid, produce a jelly of which the Hawaiians are very fond. Limu manauea is considered by native cooks especially fine when boiled with chicken, as it thickens the broth. Sometimes grated cocoanut and cocoanut milk are added to the chicken, forming a very delicious fricasse, which the writer has tested with very great appreciation. The writer has tried nearly all of these gelatinous limus with boiled beef and in beef or other soups, and finds them excellent. They are particularly palatable in vegetable soups, and are probably equally good in chicken or mutton broth, where the limu would make an excellent substitute for tapioca or sago, so often used by American cooks. Limu eleele, being a general favorite and so widely distributed, forms a part of every native feast. After being thoroughly soaked and washed in fresh water it is salted slightly and served uncooked, with poi and fish or meats. It is sometimes put into hot gravy or broth and in meat stews just before being served. It may be kept with a little salt about a week. Some natives allow it to pass through what they call a ripening process, which is as follows: The limu is soaked twenty-four hours or more in fresh water after being cleaned, when it begins to change color, becomes yellowish, slimy, and decomposes somewhat, developing a very rank odor. It is then said to be ripe and ready to eat. When sold in the market it is usually freshly prepared the day before, so is generally eaten without ripening or decomposing.

Limu aalaula, Limu kala, limu moopuna-ka-lipoa, and sometimes limu pahapaha pass through very much this same process of ripening before they are served by some of the Hawaiians in certain localities. Limu kala when ripened in this way is separated from the stems and floats, as only the leaves are eaten. Limu kala is more often eaten fresh and without any preparation whatever. Just as it is taken from the sea it is broken into convenient pieces and serves as a relish with raw fish or squid, which are frequently eaten on the beach as soon as they are taken out of the water and almost before they are dead.

The edible fresh-water algæ are often subjected to the ripening process described above. There are a number of these fine green algæ much alike in appearance called limu palawai, or lipalawai, limu nehe, and limu haulelani, which are usually found in the cool, swift mountain streams or pools. They are all the green threadlike forms of Cladoph- 
ora nitida, Spirogyra sp. (?), Hydrodictyon reticulatum, Pithophora affinis, P. polymorpha, Stigeoclonium amonum, S. sp. (?), and other species unidentified, probably Spirogyra and Cladophora. These freshwater algæ are sometimes taken fresh from the stream and eaten with fresh-water shrimps or opai and a little salt. These fresh-water limus are also occasionally cooked with pig in the imu, or put into the gravy. Most of the fresh-water algæ are eaten by the natives living in the mountain valleys, as the people on the beach seem to prefer their own more accessible seaweeds.

There is a flowering plant found in fresh-water ponds that is eaten by the Hawaiians with great relish, especially with raw opai. This flowering plant (Naias major) is called limu kala-wai because it resembles slightly the limu kala from the sea. It is eaten raw with a little salt, much as water cress. It is considered particularly appetizing with raw fresh-water shrimps, opai, or crabs. It is often sold in the market during February and March, when it seems to be most abundant.

Limu lipoa is very often pounded and mixed with other seaweeds to give them its peculiar penetrating, spicy flavor and odor. It is frequently served with meats or put into the gravy or stews to give to them a peppery flavor, of which the Hawaiians are very fond. All Hawaiians like the odor and flavor of this alga, especially with raw fish. It is considered particularly delicious with raw flying fish, if simply broken and salted slightly. This seaweed has a very agreeable spicy taste and odor, and undoubtedly takes the place of sage and pepper in Hawaiian foods.

Limu kohu is always pounded well as it is being cleaned to free it from adhering bits of coral, and also so that it may be soaked more thoroughly to remove the disagreeable bitter flavor. It is soaked twenty-four hours or more in fresh water, to remove the bitter iodin flavor. It is then salted ready to be served as a relish or salad with meats, fish, and poi, or it is mixed with other seaweeds and put into hot gravy and meat stews, just as many other limus are eaten. Limu kohu has a rather pleasant flavor, though it is slightly bitter even after soaking twenty-four hours. It is always found in the market made into balls about the size of a large baselfall and heaped upon large plates. It sells at 25 cents per ball and is always in great demand.

A very delicious condiment called inomona is made of the roasted kernel of the $\mathrm{kukui}^{a}$ nut pounded fine with salt. Many Hawaiians also add a bit of chopped chili pepper and some limu, usually limu kohu, which is pounded very fine and then thoroughly mixed with the

$a$ The kukui tree or candlenut (Aleurites mollucana) grows abundantly in our mountain valleys and mountain sides, bearing oily nuts, which were strung on grass and burned for torches or candles in ancient times. The oil was extracted and burned in stone lamps. The nuts are edible if roasted. 
pounded kukui nuts and salt. This will keep for months in glass jars, and is excellent with bread and butter or cold meats. It resembles Russian caviare in flavor, especially when eaten with bread and butter. The Hawaiians serve this with poi, raw or cooked fish, or roast meats as a relish or condiment. Other limus as limu lipeepee or limu manauea are also sometimes used in making inomona, and if chili peppers can not be obtained, the large green peppers are cooked in ti leaves, then pounded and used instead. The dried gills of the squid roasted in ti leaves are also added by some Hawaiians.

Limu luau or limu lipahee, as it is called in Hawaii (Porphyra leucosticta), is prepared by washing in the usual way in fresh water. It is then salted a little and put into clear water, where it becomes slippery and colors the water a lovely violet color. Sometimes opihi, a kind of limpet or mollusk, is put in with the limu and salt and water and placed in bottles or jars. This is used as needed, for it keeps many weeks when placed in the weak brine with the limpets. The tender tips of limu pahapaha are sometimes prepared by rubbing and crushing between the fingers, and then it is mixed with small mollusks of a special kind and salt. The finely pounded limu uaualoli is sometimes mixed with salt and small limpets in very much the same way.

The soft parts, particularly the eggs and sperm, of several kinds of sea urchins are salted and mixed with limu uaualoli, limu kohu, or other pounded limus, and this mixture is served and always eaten raw for a relish or entré. In the same way loli (several species of holothurians, as sea cucumbers, bêche de mer, and others) are cut into small pieces and mixed with pounded limu, salt, and sometimes a little chili pepper is added and then served uncooked.

Limu lipahapaha is sometimes boiled with squid, just as limu huna, and forms a gelatinous mass when cold. Limu ekahakaha is sometimes simply pounded and mixed with limpets and sometimes it is cooked with the limpets and seasoned with chili peppers and salt.

Limu aalaula is often pounded very fine and mixed with pounded salted squid, while chili peppers may also be added if preferred. It is also sometimes pounded with other seaweeds to be eaten with poi and fish or meats.

Limu kala is sometimes broken into small pieces and soaked in fresh water until it turns dark and soft, then stuffed into salmon before it is roasted, or it is chopped with fish heads and salt. Again it is sometimes ripened by putting in water with a few mollusks called leho, salted slightly, and allowed to stand several days before eating. Limu kala is more often than any other limu eaten on the beach, without any preparation other than rinsing off the sand and breaking into convenient pieces for eating with raw fish or squid. It is also sometimes put into meat gravies or stews just as it is served.

Limus when eaten raw and crisp with a little salt, or with chopped 
chili peppers added, are very pleasant appetizers with meats or fish. The writer thinks that the Americans and Europeans would find them more palatable with the addition of vinegar or lemon and pepper, or possibly an oil dressing. They serve much the same purpose in the Hawaiian diet as our salads, and certain varieties certainly have a very pleasant saline flavor and crispness.

Sometimes various shellfish, as crabs, shrimps, small mollusks, and holothurians or sea cucumbers, are chopped into small pieces and then mixed with the pounded limu and salt and often bits of chili pepper are added to the mixture. This is served with poi, meats, or fish.

Certain seaweeds are always used with certain kinds of fish or mollusks, because their peculiar flavors are considered best when blended together. Shellfish and mollusks are usually eaten raw, and that is probably why chili peppers are usually added, just as with raw fish, to sharpen the flavor, which alone is rather insipid.

\section{THE MOST POPULAR VARIETIES OF LIMUS.}

The three limus which are most popular and in the most general use by natives on all the islands are limu eleele, limu kohu (Pl. V), and limu lipoa. None of the other limus are so widely distributed on all the islands nor found in sufficient quantities to be in such general use and favor, except limu pahapaha and limu kala. Neither of these is popular with many Hawaiians, so they are used but little, even though abundant on all the islands.

Next in favor are limu manauea (Pl. VI, fig. 1), limu huna (Pl. VI, fig. 2), and limu pakaeleawaa (PI. VII, fig. 1), though the latter is native only on the islands of Hawaii and Maui. It was transplanted by certain chiefs to a few places on Oahu and Molokai. The writer was unable to find any specimens of this limu on Kauai or Niihau when collecting on these islands during the summer of 1905, yet several natives insisted that it occurred in Kauai.

Limu luau is considered a great delicacy in the few localities where it occurs, but it lasts so short a season, is so scarce, and so difficult to get that it is not very widely known. Only on northern Kauai, northern Maui, and northern Hawaii is it in use or in great favor, as it does not occur in other places, except a few scattered plants on Molokai and Oahu.

\section{METHODS OF PRESERVING SEAWEEDS.}

The Hawaiians usually preserve their seaweed, if only to be kept a few days or a week, by simply salting and tying closely in several layers of ti leaves and placing in a shady place. The ti leaves keep the seaweed from drying and also keep it crisp. The pounded seaweed is often stored in calabashes or glass jars after it is salted or put into weak brine. 


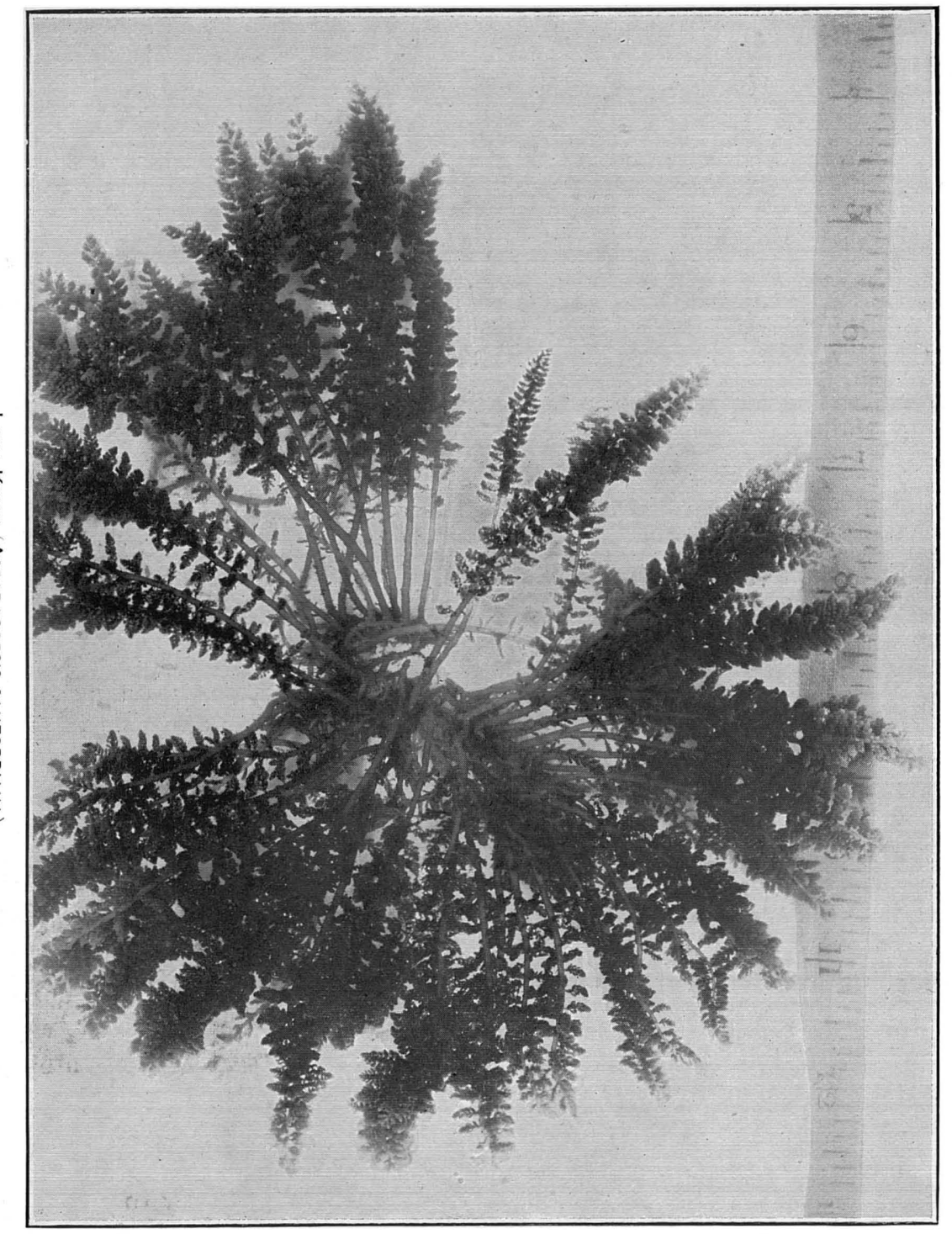




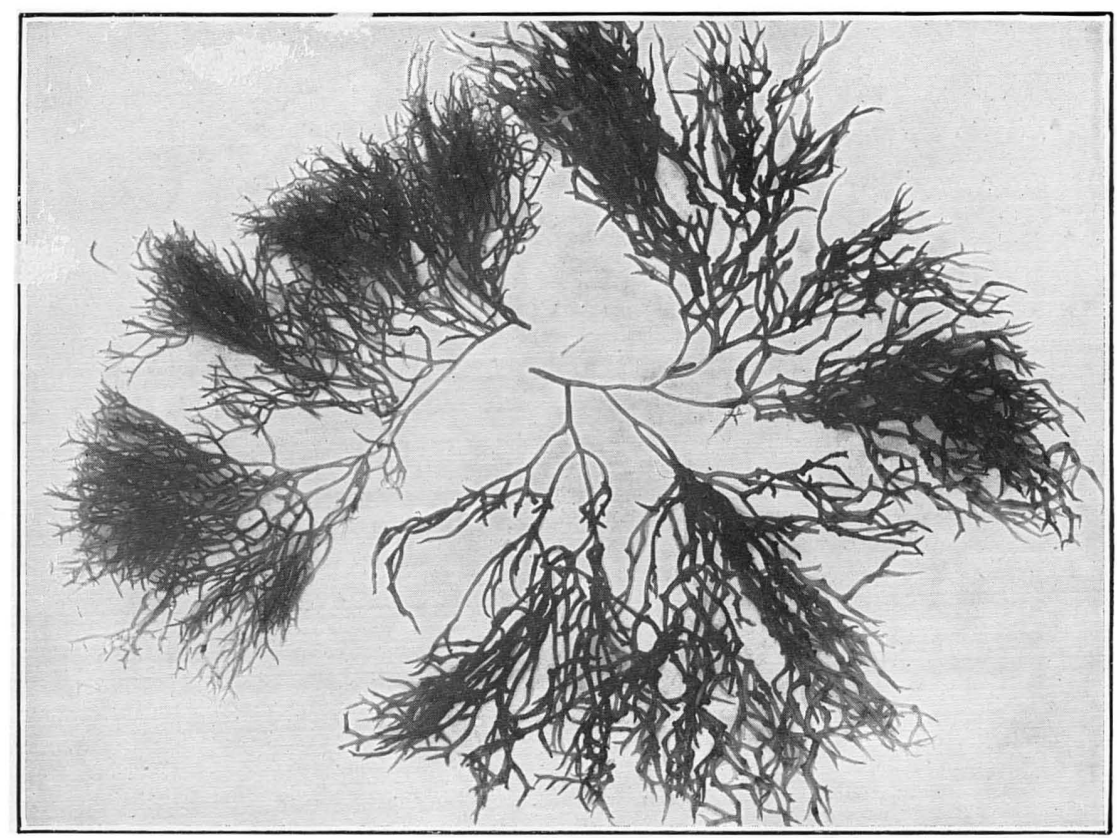

Fig. 1.-Limu manauea (Gracilaria coronopifolia).

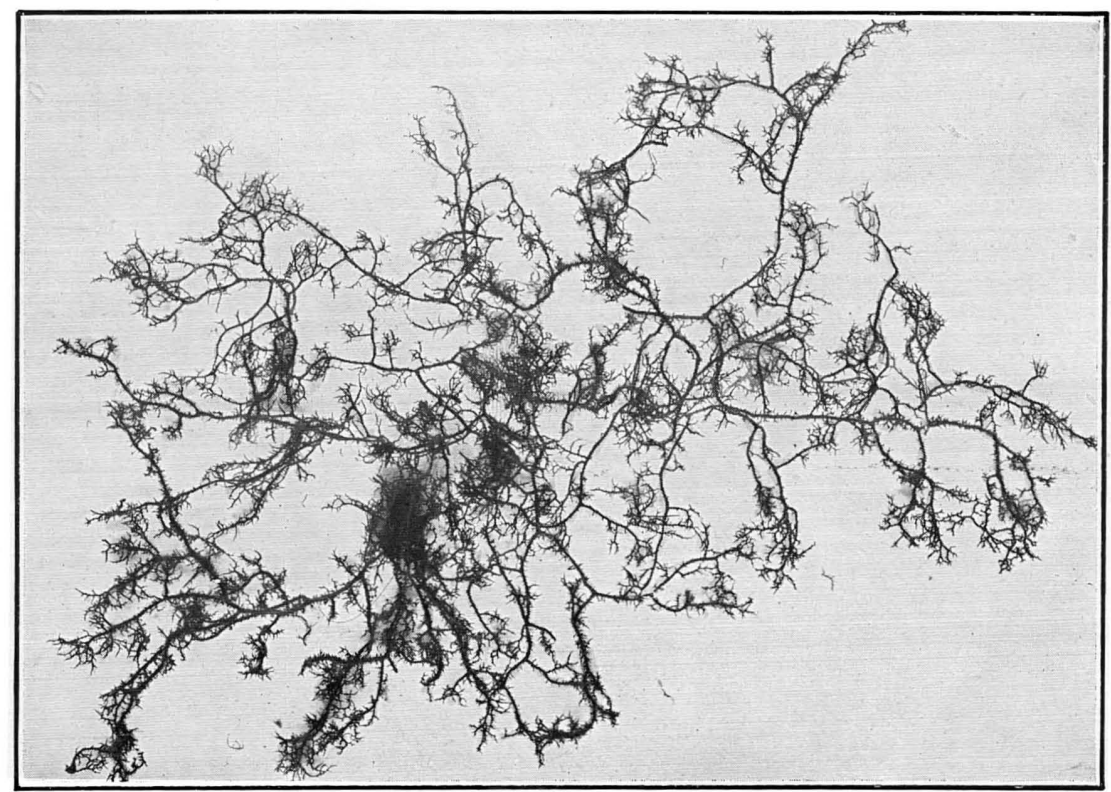

FIG. 2.-LIMU HUNA (HYPNEA SP.). 


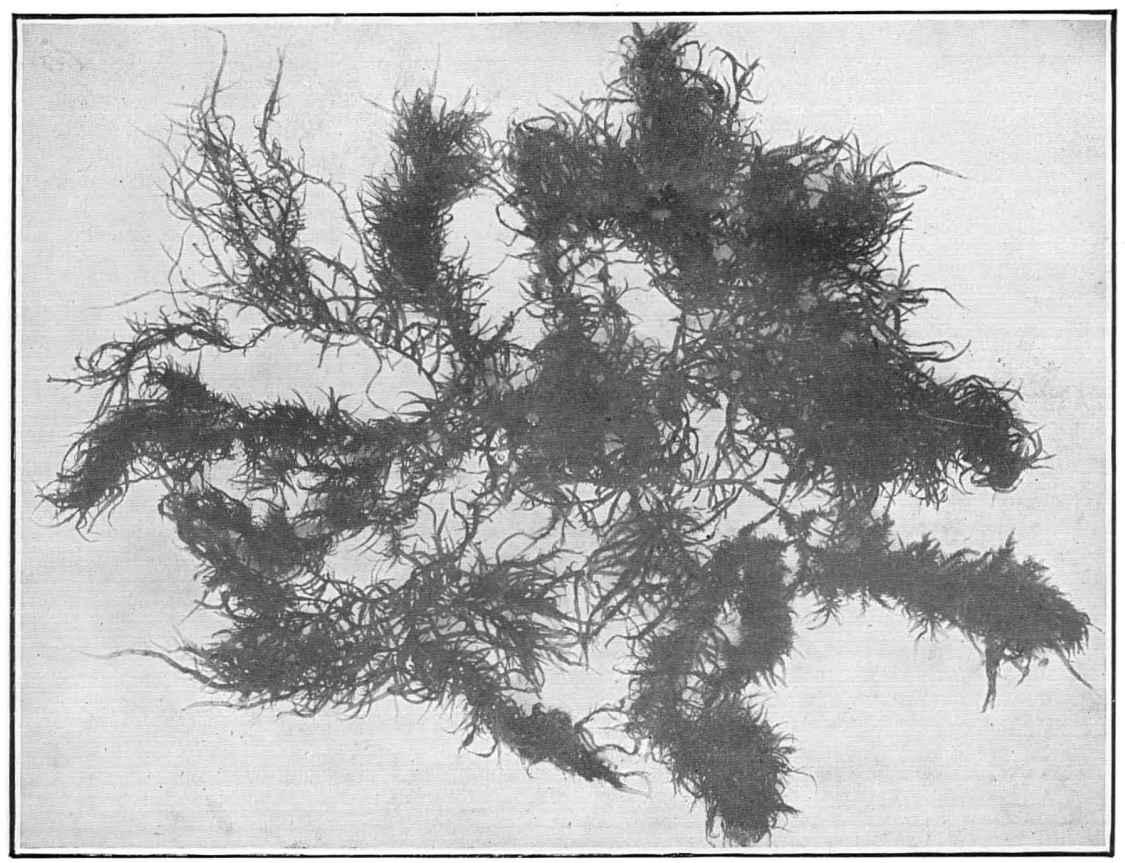

Fig. 1.-Limu PakaeleawaA (Grateloupia filicina).

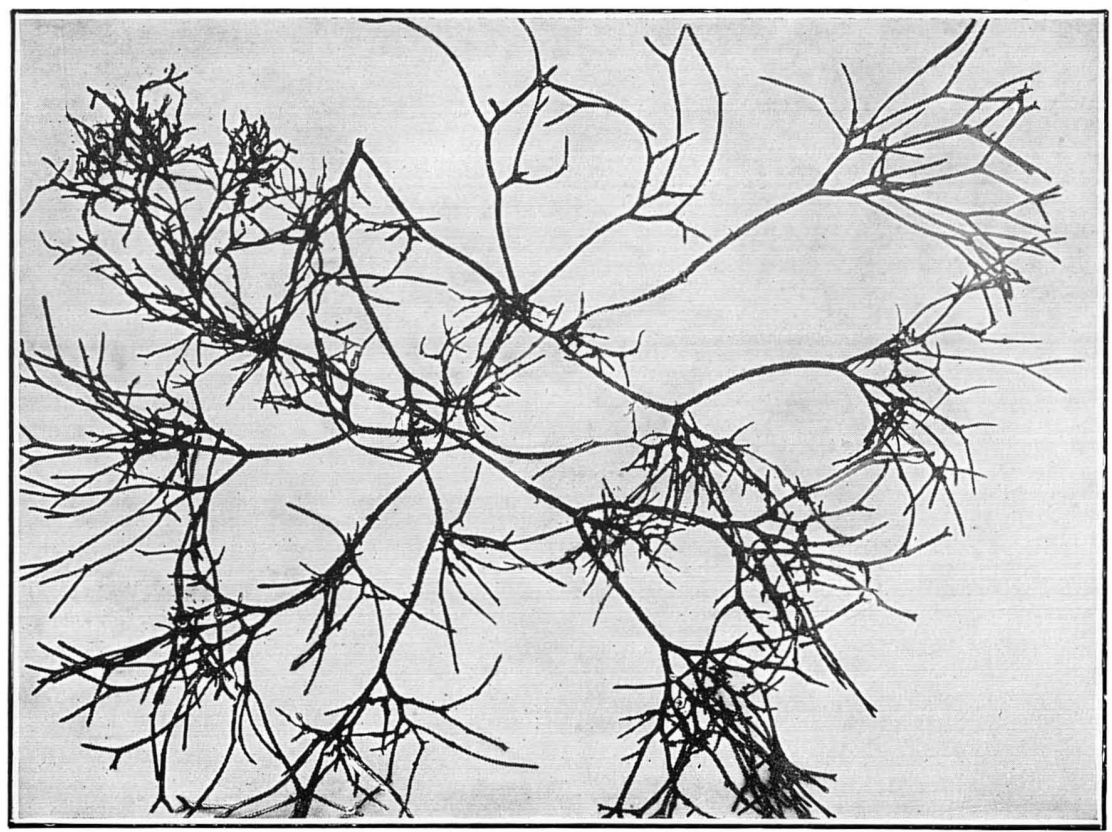

FIG. 2.-LIMU AKIAKI (AHNFELDTIA CONCINNA). 
Limu kohu, limu pakaeleawaa, limu liopa, and limu luau will keep many months, or even a year, when thus preserved. Limu lipoa is not usually kept very long, not more than a few weeks. Most all the other limus in common use are only kept from one or two days to a week, depending upon the weather and the locality. If limu is placed on ice it keeps considerably longer.

Limu pahapaha and limu pakaeleawaa are occasionally kept indefinitely by simply drying without washing off the sea water. Hawaiians very seldom use this method of preserving the limu, as they seem to think that it would be spoiled if allowed to dry. But few Hawaiians seem to know that almost all the seaweeds on the Hawaiian coast can be dried without any perceptible injury either to color, flavor, or texture. The writer has tried almost every species of Hawaiian seaweeds, and with two or three exceptions it was impossible to tell the dried specimens from the fresh if they were first soaked an hour or two in salt water. If fresh water is used for soaking or washing seaweeds it often removes the coloring matter either of the fresh or dried limu. Therefore it is best to add as much salt as is found in normal sea water when washing or preparing seaweeds, either for food or for specimens.

THE IIMUS IIOST ABUNDANT AND EASILY GATHERED.

Perhaps the limus most abundant and widely distributed over all the islands are the various kinds of limu kala, and next, perhaps, are several kinds of limu pahapaha, which are found on all the islands and in considerable quantity. Limu huna and limu manauea are very abundant on the islands of Molokai, Oahu, and Kauai, and especially on the leeward side and where there are low shallow beaches and wide coral reefs. Limu huna is scarce on Maui and not reported from Hawaii at all and was not observed there by the writer when collecting. Limu manauea is less abundant on Hawaii and Maui than on the other islands. Limu akiaki occurs in large quantities on the submerged black lava of Kauai, Oahu, and Hawaii, but is plentiful in a few localities on the other islands. At one time it was tabooed except for the chiefs. Limu loloa is most abundant on the islands of Kauai, Molokai, and Oahu, but is found in considerable quantities on the other islands. Most of the limu uaualoli is found chiefly on Maui and Molokai, but is rather scarce on Hawaii. Limu pakaeleawaa is only plentiful on the island of Hawaii on the southeast coast, but is found in limited quantities on Maui, Molokai, and Oahu, having been transplanted to the last two islands. Limu eleele is found in large quantities in the brackish water at the mouth of all the streams that are not too swift.

All the limus mentioned above are easily gathered except limu uaualoli, which grows on the stormy side of the islands on the most 
exposed rocks, so unless the weather is very calm it is rather difficult to secure in large quantities.

Limu oolu grows in shallow water near shore or farther out on the shallow sand-covered reefs where the water is quiet, hence is quite easily gathered, but it occurs in rather limited quantity in but a few places.

All the other limus are more difficult to gather and also occur in more limited quantities and in but few localities. This is especially true of limu luau, which is extremely difficult to collect and is very searce. It grows only on the most exposed and slippery rocks, and disappears in a few days after the stormy weather subsides not to reappear until the next season immediately after the heavy winds. Therefore this much-prized limu is always most difficult to obtain even in very small quantities.

Limu kohu, which is so eagerly sought, grows usually far out on the exposed rocks or on coral reefs, where the breakers dash, so is rather difficult to get even in quiet weather and impossible in heavy storms. Occasionally, however, it grows on reefs less exposed and more accessible.

Limu lipoa is limited to certain localities, and occurs in rather small quantities. It grows in rather deep water, so usually can be gathered only by diving or swimming. It is found in small quantities on all these islands, and is a general favorite.

Limu huna and limu manauea are often drifted upon the beach by the heavy winds or high tides, and may be very easily gathered in boat loads by wading along the shallows at low tide and gathering up the drift on the shore and at the water's edge. It is especially abundant where there are very wide coral reefs under shallow water and a sandy bottom. There are tons and tons of these two limus on the south coast of Molokai, south and east Kauai, and almost all around Oahu, except off Kaena Point and in the harbor, where the water is too deep or muddy for seaweeds to thrive. Wherever there are shallows or reefs off Maui it is also plentiful, though not in such large quantities as the other islands mentioned, because of a less favorable coast.

Limu manauea and limu huna are most abundant in early spring and during the summer months, though both are found in considerable quantities all the year, as would naturally be expected in a tropical region.

Limu loloa can be secured in large quantities all the year round on Molokai, Oahu, Kauai, and Maui, but is not so abundant on Hawaii. It grows on the great lava rocks exposed to waves, so in heavy storms it is difficult to secure.

Limu akiaki (Pl. VII, fig. 2) may be obtained by boat loads all the year, if not too stormy, as it also grows on the great black lava rocks 
exposed usually to heavy surf. Sometimes it grows in quiet coves or behind the great lava rocks alongshore in less exposed places, but never in shallow water.

\section{VATIVE METHODS OF CULTIVATING LIMUS.}

The writer was much surprised to learn that a rude kind of cultivation of the much-prized limu kohu was practiced at Moloaa, on Kauai. Here limu kohu grows very luxuriantly over the entire reef, and is the finest in color and flavor found on this group of islands.

There is a small cove just beyond Moloaa Bay to the northward, which is partly protected from the heavy trade winds and southerly storms by bold, rocky bluffs or headlands. The coral reef extends from the shore out perhaps a half mile and beyond the headlands, so that the whole cove has rather shallow water. The coral rock, the usual haunt of the limu kohu, is in this place somewhat protected from storms, so the natives can gather this limu almost any time of the year, when the tide is low, without danger from heavy breakers.

The Hawaiians living at Moloaa gather limu kohu for the Honolulu market regularly, making a nice little income from its sale, as they furnish the larger share of the supply. It is here that these limu gatherers have attempted to increase their sales by caring for their seaweed to the extent of weeding out all the other algæ, and thus, no doubt, increasing the quality and quantity of limu kohu, which here is so much finer and more luxuriant than in any other place. This is the only place of which the writer has heard where the limu is actually weeded and cared for as a garden. There are, however, several places where a certain favorite limu has been transplanted from other islands and guarded carefully until it could get established. Limu pakaeleawaa was transplanted from Hawaii to Molokai by an old chief,' who planted it on the inner edge of his fish pond, where it is now growing luxuriantly. This same limu has also been transplanted to the beach in front of the residence of ex-Queen Liliuokalani, near Diamond Head, and also in front of her Waikiki place. It is thriving in both places, so the writer has been told. This last summer, when collecting on the north side of $\mathrm{Oahu}$, in Kaneohe Bay, the writer was much surprised to find limu pakaeleawaa growing luxuriantly on the rocks near shore. The native fishermen said that it had been planted there many years before by a chief, who brought it from Hawaii. In all these instances there is an attempt to aid nature, and so a crude kind of limu culture is practiced in Hawaii, though, of course, it is not so extensive or systematic as that in Japan. There may have been more attempts at cultivating or transplanting seaweeds by the natives of the past, for no doubt when a chief moved from one island to another he brought with him his best taro and yam plants for his lands; why not his favorite.limus to his fish ponds or beach? 


\section{VALUE AND AMOUNT OF NATIVE SEAWEEDS SOLD IN HONOLULU.}

It would be rather difficult to tell the exact amount or value of all the seaweed sold each year in Honolulu, but it is possible to make a fairly accurate estimate from the market inspector's report and the Chinese merchants' statements.

The inspector of the fish markets reports the annual sale of 4,800 pounds of limu, valued at about $\$ 2,500$. It is sold almost exclusively to the Hawaiians or part Hawaiians. Of this total about 2,000 pounds is limu kohu, which is worth about $\$ 1,000$ at retail. The remaining amount is about two-thirds to three-fourths limu eleele and limu oolu. All the rest are comparatively scarce or not so popular, so are only in the market occasionally during certain seasons of the year. Limu kohu is always in the market, while the other limus are usually found only on Saturdays and the day before holidays.

The following limus are found in the Honolulu fish market, either regularly or at intervals, according to the season or the weather: Limu kohu (Asparagopsis sanfordiana), limu eleele (Enteromorpha prolifera, E. flexuosa, E. intestinalis, E. hopkirkii, and E. plumosa), limu oolu (Chondria tenuissima), limu lipeepee or limu maneoneo (Laurencia papillosa, L. pinnatifida, L. virgata, L. obtusata), limu manauea (Gracilaria coronopifolia), limu lipoa (Dictyota acutiloba and Haliseris plagiogramma), limu kalawai (Naias major), and occasionally limu huna.

Usually these native limus are cleaned, pounded, and salted all ready for serving before they are offered for sale in small plates or saucers. These plates contain from a half pound to a pound of the limu, which sells at from 5 to 25 cents per plate, depending upon the kind. A few varieties like limu lipoa, limu lipeepee, limu manauea, limu huna, and limu kalawai, or fresh-water kala, are sold in loose handfuls, with no preparation except washing off the sand. Every native who buys a fish or a lobster also buys his plate or handful of limu.

Limu kohu is always pounded fine enough to be pressed into balls before it is packed with salt in tins or barrels to be shipped to Honolulu market. When retailed it is made into balls about the size of a large baseball and weighing about a pound. They always sell at 25 cents each, though the balls are smaller in stormy weather when limu kohu is scarce. All these limus are very moist, so they are always tied up neatly in fresh green ti leaves when purchased to prevent the water from leaking out upon the buyer's clothes. The ti leaves also keep the limu fresh and moist and never soak up the water as paper does if tied about something wet.

Nearly all the limu is sold in the market by native women, who have other Hawaiian delicacies, as sea urchins, roasted kukui nuts, crabs, cocoanut pudding, small cubes of raw beef liver, ready to serve with limu, etc.

The amount of limu sold in Honolulu does not of course include nearly all that is actually consumed either on these islands, on Oahu, or even 
in Honolulu, as every native family living on or near the beach gets its own supply of algæ fresh from the sea whenever it is desired.

\section{VALUE OF SEAWEEDS IMPORTED BY ORIENTALS INTO HAWAII.}

The Japanese and the Chinese of Hawaii use a large quantity of seaweed of various kinds, either prepared in various ways or simply roughly dried. The Orientals seldom use the Hawaiian algæ, as they prefer that cured and prepared in their own country. This is sold only in the Chinese or the Japanese grocery shops.

Most of this imported seaweed comes from Japan ana is either kombu or wakame and its various preparations. The Japanese consular report for 1904 says the amount of seaweed sold to Hawaii and to the United States was as follows:

Japanese seaweed sold to Hawaii and the United States, 1904.

\begin{tabular}{|c|c|c|}
\hline Seaweed from Japan. & .Weight. & Value. \\
\hline 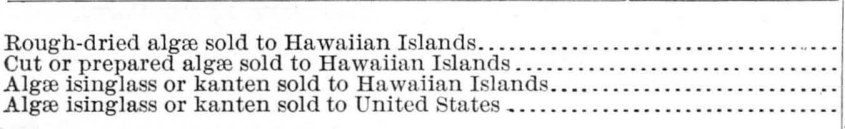 & \begin{tabular}{r|} 
Pounds. \\
$112,492.73$ \\
$40,789.77$ \\
$1,751.61$ \\
$61,588.31$
\end{tabular} & $\begin{array}{r}\$ 1,597.15 \\
876.14 \\
470.72 \\
15,152.30\end{array}$ \\
\hline Total. & $216,622.42$ & $18,086.31$ \\
\hline
\end{tabular}

Nearly all the seaweed preparations described by Hugh M. Smith in his Report of the Japanese Seaweed Industry are sold here in Honolulu by the Japanese grocers to our Japanese population. The different seaweeds and their preparations vary in price from 5 to 30 cents per pound retail. The kanten costs about $\$ 1.50$ or $\$ 1.65$ per pound, and it is extremely light for its bulk. Amanori sells in small, thin sheets about 5 by 12 inches for 10 cents per dozen sheets. These sheets are almost as light as paper. Kombu and wakame are sold in the largest quantities, and are boiled to serve with rice, fish, and vegetables.

The Chinese import large quantities of seaweed each year, but there are no consular reports that give the amount or its value; so the following figures are taken from various estimates made by intelligent and responsible Chinese merchants who import this commodity. There are probably 70,000 to 80,000 pounds of seaweed, valued at from $\$ 10,000$ to $\$ 12,000$, imported and sold annually by the Chinese grocers of Honolulu.

The prices of these Chinese seaweeds vary from 10 or 15 cents per pound retail for che choy or kum choy (Porphyra perforata and $P$. nereocystis), 7 to 35 cents per pound for toi choy, hoy tai, and san choy (all Laminaria sp.), and 75 cents to $\$ 1.50$ per pound for fat choy (Nostoc commune flagelliforme).

The most expensive varieties of seaweed are not sold in large quantities, and of course are purchased only by the most prosperous class of Chinese for feasts and holidays. Fat choy is used in very small quantities, as it is extremely light, swelling greatly in water when 
soaked or cooked, so that an ounce makes a considerable bulk when ready to serve. This is also true of most dried seaweeds, and especially of the common kombu, wakame, and che choy.

Che choy (Porphyra perforata) is imported from San Francisco and is a substitute for a Chinese alga called tsu choy (probably Porphyra orbiculata and $P$. tenera) which is greatly prized by the Chinese. It costs from 75 cents to $\$ 1$ per pound when imported from China and keeps very poorly, often spoiling soon after its arrival; hence the use of the cheaper che choy from San Francisco. This retails here at 12 to 15 cents per pound, and is said to be almost as good as the Chinese variety. The tsu choy is imported only in small packages for the New Year feasts and sold to a few Chinese epicures.

One Chinese wholesale grocer said that he imported annually two or three tons of che choy, which costs from $\$ 600$ to $\$ 700$. He estimated that from 25 to 30 tons of this seaweed was imported yearly from San Francisco, costing from $\$ 6,000$ to $\$ 7,000$.

The Chinese use seaweed very much in the same way as the Hawaiians. They cook it in soups, stewed meats, or gravy, and also make it into pickles, preserves, or candies and other sweetmeats.

\section{USE OF LIMUS FOR MEDICINE AND INCANTATIONS.}

The writer has been unable to gather much data regarding the medicinal uses of limu, yet the few items collected are of considerable interest. Certain green fresh-water algæ, species of Spirogyra and Cladophora, are said to heal sore eyes if tied on as a poultice. Limu kala is pounded with salt and bound about bruises and cuts to relieve pain. Limu huna is sometimes boiled and the hot infusion given for stomach ache. Limu eleele is dried and put on boils, or it is sometimes used fresh and moist to poultice boils. Limu pahapaha is pounded and put on bruises. Lima luau is pounded to a pulp with salt and the juice is used to moisten bandages on cuts or bruises. Limu eleele and limu palawai are both pounded with salt and tied on cuts and bruises. Limu maneoneo is pounded with salt and the juice is put on cuts or bruises. A species of Centroceras, probably $C$. clavulatum, is pounded with salt and put on bruises and sores. An infusion of this same alga, when cooked, is given for a cathartic.

Limu kala is used by the kahunas or witch doctors in incantations to drive away sickness. The superstitious native when ill gathers limu kala, makes a lei for head or neck, eats some, says a prayer of penitence, promises to do better, then goes into the sea. He must not look back, speak, or beckon to anyone until he takes the limu lei, places it on head or neck, eats a bite of it, then throws the lei back into the sea, still looking out to sea and praying for forgiveness. This ceremony is said to cure if it is faithfully carried out.

It is believed that a most effective love potion is made from limu kalawai, or fresh-water limu kala as it is often called. The lovelorn 
maiden says over a magic spell learned from a kahuna, eats the limu kala, then gives some to the one whose love is desired. Straightway he adores her. Limu awikiwiki (Gymnogongrus vermicularis) was used also in love-making charms in ancient days, and was probably equally effective.

\section{CHEMICAL ANALYSES AND COMPARATIVE FOOD VALUES OF SEAWEEDS.}

The algæ when gathered are very succulent and contain a large amount of water. Considerable of this moisture is lost in the various methods of preparation for the table or for other uses. A number of specimens of Hawaiian algæ were analyzed by Mr. R. A. Duncan, food chemist of Hawaii, in connection with the writer's investigation of this class of plants, and the results are given in the table below, together with some similar analyses which have appeared in earlier publications of the Office of Experiment Stations and elsewhere. All the samples analyzed were air dry.

Composition of edible algæ.

[Air-dry material.]

\begin{tabular}{|c|c|c|c|c|c|c|}
\hline \multirow[t]{2}{*}{. } & \multirow[b]{2}{*}{ Water. } & \multirow[b]{2}{*}{ Protein. } & \multirow[b]{2}{*}{ Fat. } & \multicolumn{2}{|c|}{ Carbohydrates. } & \multirow[b]{2}{*}{ Ash. } \\
\hline & & & & $\begin{array}{l}\text { Sugar, } \\
\text { stareh, } \\
\text { etc. } a\end{array}$ & $\begin{array}{l}\text { Crude } \\
\text { fiber. }\end{array}$ & \\
\hline 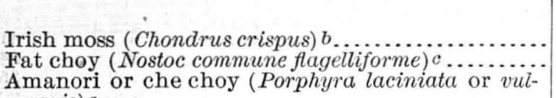 & $\begin{array}{l}\text { Per ct. } \\
18.8 \\
10.58\end{array}$ & $\begin{array}{l}\text { Per ct. } \\
9.4 \\
20.93\end{array}$ & Per ct. & $\begin{array}{c}\text { Per ct. } \\
55.4 \\
55.73\end{array}$ & $\begin{array}{l}\text { Per } \text { ct. } \\
2.2 \\
\quad 4.07\end{array}$ & $\begin{array}{l}\text { Per ct. } \\
14.2 \\
\quad 7.50\end{array}$ \\
\hline 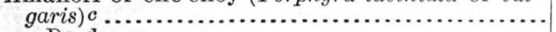 & 21.85 & 25.70 & .17 & \multicolumn{2}{|c|}{37.68} & 14.60 \\
\hline . & 15.48 & 34.35 & .65 & \multicolumn{2}{|c|}{38.83} & 10.69 \\
\hline Do.d... & 20.42 & 36.26 & 1. 21 & \multicolumn{2}{|c|}{33.28} & 8.83 \\
\hline 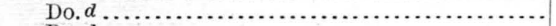 & 16.40 & 35.63 & .50 & \multicolumn{2}{|c|}{38.13} & 9.34 \\
\hline 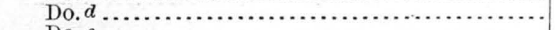 & 14.58 & 32.44 & .70 & \multirow{2}{*}{\multicolumn{2}{|c|}{$\begin{array}{l}43.28 \\
41.22\end{array}$}} & 9.00 \\
\hline 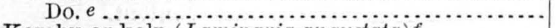 & 13.98 & 33.75 & 1.30 & & & 9.75 \\
\hline Kombu or kelp (Laminaria angustata) $f \ldots \ldots \ldots$....... & 22.82 & 5.49 & 1.52 & 46.93 & 4.55 & 18. 69 \\
\hline Kombu or kelp (Laminaria longissima) $f . . . . . .$. & 25.94 & 6.72 & 1. 73 & 31.90 & 6.42 & 27. 29 \\
\hline Kombu or kelp (Laminaria japonica) $f$............ & 22.97 & 4. 96 & 1.59 & 47. 49 & 5.83 & 17. 16 \\
\hline Kombu or kelp (Laminaria ochotensis) $f$... & 23.99 & 6.65 & .86 & 42. 16 & 6.03 & 20.31 \\
\hline Kombu or kelp (Laminaria religiosa) $f$..... & 22.75 & 4. 72 & .82 & 42.88 & 10.20 & 18.63 \\
\hline Kombu or kelp (Laminaria fragilis) $f . . . . . . . . .$. & 23.10 & 4. 03 & .65 & 40.41 & 7.15 & 24. 66 \\
\hline 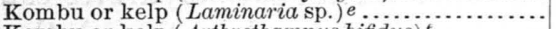 & 23.08 & 7.11 & .87 & \multicolumn{2}{|c|}{47.70} & 21. 24 \\
\hline Kombu or kelp (Arthrothamnus bifidus) $f \ldots \ldots \ldots$. & 24.43 & 5.82 & .74 & 45.58 & 6.44 & 16. 99 \\
\hline 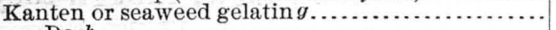 & 22.80 & 11. 71 & $\ldots$. & 62.05 & & 3.44 \\
\hline 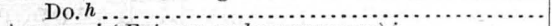 & 22.29 & 6.85 & $\cdots$ & 60.32 & 6.73 & 3.81 \\
\hline Awo-nori (Enteromorpha compressa) $i \ldots$ & 13.60 & 12.41 & \multicolumn{3}{|c|}{52.99} & 10.42 \\
\hline Awo-nori (Enteromorpha linza) e...... & 13.53 & 19. 35 & 1.73 & \multicolumn{2}{|c|}{46.18} & 19. 21 \\
\hline Limu akiaki (Ahnfeldtia concinna) $j \ldots \ldots \ldots \ldots \ldots$ & 20.16 & 5. 60 & .07 & 54. 96 & 2.66 & 16.55 \\
\hline Limu pahapaha (Ulva fasciata and $U$. lactuca) $j \ldots$ & 18. 68 & 14. 87 & .04 & 50.65 & .19 & 15.57 \\
\hline Limu manauea (Gracilaria coronopifolia) $j \ldots . .$. ... & 12.87 & 7.91 & .05 & 58.41 & 2.98 & 17. 78 \\
\hline 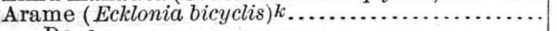 & 13.17 & 8.99 & & 45. 70 & 7. 40 & 24.74 \\
\hline$\ldots \ldots \ldots \ldots \ldots \ldots$ & 18.75 & 9.58 & .46 & 51.63 & 9.79 & 9.79 \\
\hline Hijiki (Cystophyllum fusiforme) $k$.... & 16. 40 & 8.42 & & 41.92 & 17.06 & 16.20 \\
\hline 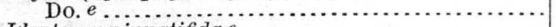 & 15.74 & 11. 37 & .49 & \multirow{2}{*}{\multicolumn{2}{|c|}{$\begin{array}{l}54.84 \\
37.81\end{array}$}} & 17.56 \\
\hline 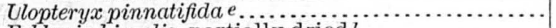 & 18. 92. & 11. 61 & .31 & & & 31.35 \\
\hline Ecklonia bicyclis, partially dried $l \ldots \ldots \ldots \ldots \ldots$ & 55.62 & 4. 96 & .40 & 13. 60 & 19.16 & 6.26 \\
\hline Laminaria, partially dried $l \ldots \ldots \ldots \ldots \ldots \ldots \ldots \ldots$ & 52.96 & 4. 11 & 1.44 & 29.68 & 5.25 & 6.56 \\
\hline 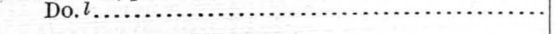 & 68.26 & 2.80 & .48 & 19.50 & 3.29 & 5.67 \\
\hline
\end{tabular}

a Computed by difference except in a few cases which were actually determined.

$b$ United States Dispensatory.

$c$ U.S. Dept. Agr., Office of Experiment Stations Bul. 68, p. 47.

$d$ Imperial Fisheries Bureau of Japan, quoted in Bul. [U. S.] Bureau Fisheries, 24 (1904), p. 160.

$e$ Tahara, quoted in T. S. Dept. Agr., Office of Experiment Stations Bul. 159, p. 40.

$\boldsymbol{f}$ K. Oshima, quoted in Bul. [U.S.] Bureau Fisheries, 24 (1904), p. 153.

$g$ O. Kellner, quoted in Bul. [U.S. S.] Bureau Fisheries, 24 (1904), p. 141

$h$ Imperial Fisheries Bureau of Japan, quoted in Bul. [U.S.] Bureau Fisheries, 24 (1904), p. 141.

$i$ O. Kellner, quoted in Bul. [U. S.] Bureau Fisheries, 24 (1904), p. 164.

$j$ R. A. Duncan, food chemist for the Territory of Hawaii.

$\imath$ Murai and Kasama, quoted in U. S. Dept. Agr., Office of Experiment Stations Bul. 159, p. 43. 
For a proper comparison the fresh algæ should be compared with succulent green foods, like spinach and bananas, or such materials as poi or taro. If the air-dry materials are considered they should be compared with such articles as dried vegetables, crackers, meal, beans, cheese, dried beef, dried fish, etc. In the following table analyses are given of a number of common articles of food, and for comparison three of the more common limus are included, which have been calculated on a uniform water basis of 80 per cent:

Composition of marine alge compared with other foods.

\begin{tabular}{|c|c|c|c|c|c|c|}
\hline$\cdot$ & Water. & Protein. & Fat. & $\begin{array}{l}\text { Carbohy- } \\
\text { drates. }\end{array}$ & Ash. & $\begin{array}{c}\text { Fuel } \\
\text { value per } \\
\text { pound. }\end{array}$ \\
\hline Limu akiaki (Ahnfeldtia concinna) a ..... & $\begin{array}{r}\text { Per cent. } \\
80.0\end{array}$ & $\begin{array}{r}\text { Per cent. } \\
1.4\end{array}$ & $\begin{array}{r}\text { Per cent. } \\
0.0\end{array}$ & $\begin{array}{r}\text { Per cent. } \\
14.4\end{array}$ & $\begin{array}{r}\text { Per cent. } \\
4.2\end{array}$ & $\begin{array}{r}\text { Calories. } \\
290\end{array}$ \\
\hline $\begin{array}{l}\text { Limu pahapaha (Ulva fasciata and } U \text {. } \\
\text { lactuca) } a . \ldots \ldots \ldots \ldots \ldots \ldots \ldots \ldots \ldots \ldots \ldots \ldots\end{array}$ & 80.0 & & & & & \\
\hline Limu manauea (Gracilaria coronopi- & 80.0 & 3.7 & .0 & 12 & 3.8 & 295 \\
\hline 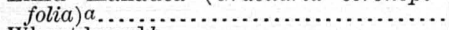 & 80.0 & 1. 8 & .0 & 14.1 & 4. 1 & 290 \\
\hline 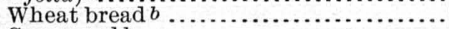 & 35.3 & 9.2 & 1. 3 & 53.1 & 1.1 & 1,185 \\
\hline Corn meal $b . . . \ldots \ldots \ldots \ldots \ldots$ & 12.5 & 9.2 & 1. 9 & 75.4 & 1.0 & 1,610 \\
\hline Crackers $c . . . \ldots \ldots \ldots \ldots \ldots \ldots . . . . .$. & 6.8 & 10.7 & 8.8 & 71.9 & 1.8 & 1,905 \\
\hline Taro $d . . . . . . . . . . . . . . . . .$. & 67.5 & 1.9 & .2 & 29.3 & 1. 1 & 595 \\
\hline 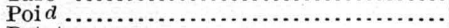 & 83.0 & .3 & .6 & 15.8 & .3 & 325 \\
\hline 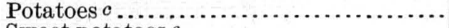 & 3 & 2.2 & .1 & 18.4 & 1. 0 & 385 \\
\hline Sweet potatoes $c \ldots \ldots \ldots \ldots \ldots \ldots$ & 69.0 & 1.8 & .7 & 27.4 & 1. 1 & 570 \\
\hline Beans, Lima, shelled $b . . . \ldots \ldots \ldots$. & 68.5 & 7.1 & .7 & 22.0 & 1. 7 & 555 \\
\hline Beans, dried $b . . . \ldots \ldots \ldots . . . . . . . .$. & 12.6 & 22.5 & 1. 8 & 59.6 & 3.5 & 1,560 \\
\hline 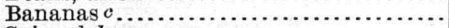 & 75.3 & 1.3 & .6 & 22.0 & .8 & 460 \\
\hline 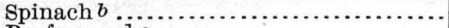 & 92.3 & 2.1 & 3 & 3.2 & 2.1 & 110 \\
\hline Beef, round $c \ldots \ldots \ldots \ldots \ldots \ldots \ldots \ldots \ldots$ & 67.8 & 20.9 & 10.6 & .......... & 1.1 & 835 \\
\hline Pork, shoulder $c \ldots \ldots \ldots \ldots \ldots \ldots \ldots \ldots$ & 51.2 & 13.3 & 34.2 & $\ldots \ldots \ldots$ & .8 & 1,690 \\
\hline 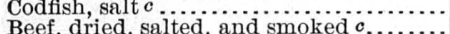 & 53.5 & 25.4 & .3 & $\cdots \cdots \cdots$ & 24.7 & 410 \\
\hline $\begin{array}{l}\text { Beef, dried, salted, and smoked } c \ldots \\
\text { Mullet } c \ldots \ldots \ldots \ldots\end{array}$ & $\begin{array}{l}54.3 \\
74.9\end{array}$ & 30.0 & 6.5 & .4 & 9.1 & 840 \\
\hline hen's $c . . . \ldots \ldots \ldots \ldots$. & 73.7 & 13.4 & $\begin{array}{r}4.0 \\
10.5\end{array}$ & 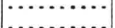 & 1.2 & $\begin{array}{l}555 \\
720\end{array}$ \\
\hline Cheese, full cream $b . \ldots . . . . . . .$. & 34.2 & 25.9 & 33.7 & 2.4 & 3.8 & 1,875 \\
\hline Rice $b .$. & 12.3 & 8.0 & .3 & 79.0 & .4 & 1,590 \\
\hline
\end{tabular}

$a$ Recalculated from figures given in preceding table to uniform water content.

$b$ U. S. Dept. Agr., Office of Experiment Stations Circ. 46 (revised).

$c$ U. S. Dept. Agr., Office of Experiment Stations Bul. 28 (revised).

$d$ E. C. Shorey, Hawaii Experiment Station.

As will be seen by the data in the above tables, carbohydrates constitute the principal nutritive material present in algæ, though they contain considerable quantities of protein and relatively high proportions of ash. So far as can be learned little information is available regarding the character of the nitrogenous material present and the proportions of albumins, which have a high food value as compared with amids or other nitrogenous extractives. As a class the algæ differ very decidedly from the usual food materials in the character of the carbohydrates present, starch being usually replaced by such carbohydrates as mannit and substances which yield on hydrolysis various galactoses, mannose, glucose, pentose, etc. ${ }^{a}$

Judged by chemical composition the air-dry algæ compare favorably with other common food materials, particularly those of vegetable

- $a$ See summary of data in U. S. Dept. Agr., Office of Experiment Stations Bul. 159, p. 34 . 
origin. It has been commonly supposed that the Irish moss, so much used in invalid dietetics, and other algæ and food made from them were very thoroughly assimilated, but recent experiments carried on by T. Saiki, at Sheffield Scientific School, Yale University, indicate that this is not the case, at least with respect to the carbohydrate constituents. That they are wholesome and are palatable additions to the diet in regions where they are eaten in quantity is well established, and it seems fair to say that they occupy much the same place in the diet as other common foods, particularly green vegetables. In order that digestion should be normally accomplished foods should be bulky, and in this respect the marine algæ would certainly prove useful. Mineral matters are needed for the formation of bones, teeth, and other tissues, and to fulfill other physiological functions. The algæ are rieh in phosphates, chlorids, bromids, iodids, etc., and it seems probable that the mineral matter which they supply must be of importance to the body. As Saiki points out, the algæ gelatins are of much importance in counteracting constipation.

\section{AMOUNT OF GELATIN OR GLUE FOUND IN HAWAIIAN ALGAE.}

The writer made some rather crude experiments to test the various common limus of Hawaii for the amount of gelatin available by ordinary boiling. The most satisfactory results were obtained from the following varieties: Limu huna, limu manauea, limu akiaki, limu kohu, limu loloa, and limu pakaeleawaa. Some others were tried, but they contained very little gelatin or were too strong in flavor to make gelatin for foods. The limu loloa made a very dark gelatin, with a rather strong flavor, so would be more valuable for making mucilage than for gelatin. In making these experiments to extract the gelatin only a small coal-oil stove and a few tin pails were available for boiling the algæ. The seaweed was carefully washed and cleaned, then boiled in clear water from 1 to 3 hours. When it seemed well softened or dissolved, it was passed through a coffee strainer, then through coarse linen doubled. It came through clear, and soon stiffened on exposure to the wind and sun. It was all dried in clear, stiff, crisp sheets on plates in a sunny window. It looked as clear and fine in quality as the best gelatins of the market.

The time of cooking, the amount of gelatin obtained, as well as the quality, varied with the kind of seaweed used. Limu manauea makes the finest, clearest gelatin, and limu akiaki ranks next, limu huna third in quality, while limu pakaeleawaa makes the poorest and smallest quantity. Limu manauea requires the least cooking, and limu huna is next, while limu loloa makes the darkest colored and strongest flavored gelatin. It would make an excellent glue, because it is very sticky, but dries hard as glue should. 
Roughly estimated, these seaweeds yield 75 to 80 per cent of their dry weight of gelatin or glue. The writer had no means of carefully weighing the materials to get the exact proportions of seaweed and the glue or gelatin obtained in order to make accurate estimates of their ratios. All the seaweeds occuring on Hawaii in large quantities were tested for gelatin with the above results. Limu uaualoli probably contains a considerable amount of gelatin, but is difficult to gather and can only be secured with some difficulty, and only in very moderate quantities on the north side of Maui, Molokai, Oahu, and Kauai. It is possible that some of the species of Laurencia as limu lipeepee and limu maneoneo might yield some gelatin, but they do not occur in large enough quantities to be of importance in this consideration.

The writer tried using some of this seaweed gelatin as mucilage for pasting on labels and pictures, etc., and found it just as satisfactory as ordinary library paste. It left no shiny mark on the edges. If kept from fermenting by some preservative it would undoubtedly be just as useful as any other mucilage.

\section{HAWAIIAN IIMUS FOR IMAKING AGAR AGAR FOR CULTURE} MEDIA.

Two small jars of the clearest, best gelatin made from limu manauea and limu huna were taken to the laboratory of Dr. N. A. Cobb, plant pathologist at the Hawaiian Sugar Planters' Experiment Station, to be tested as culture media. He reported them to be quite satisfactory for cultures of various fungus diseases. No doubt if this gelatin were mixed with beef tea, milk, or other suitable foods it would make just as satisfactory a medium for the culture of the bacteria. If we could produce our own agar agar in the United States it would of course save importing it from abroad. Most of the agar agar used in the laboratories of the United States and Europe is made from the algæ of Japan and Ceylon or Java. It is prepared partly in Japan, but the best quality is sent to Germany to be manufactured. We have tons of gelatinous algæ here in Hawaii that would make the best quality of agar agar if we chose to manufacture it ready for the bacteriologist.

\section{FURTHER UTILIZATION OF HAWAIIAN SEAWEEDS FOR FOOD, GELATIN, FARINA, GLUE, AND MUCILAGE.}

It is not probable that raw seaweed prepared in the usual Hawaiian style would ever be generally popular with the American or European, who naturally prefers his own salads and relishes to which he is accustomed. Even those having the most pleasant saline flavor and crispness, as limu kohu, limu manauea, limu huna, and limu pahapaha, or limu lipoa, with its peculiar pleasant spiciness have in addition a slight flavor that suggests the sea, to which many people object. It is only 
after tasting several times that many people come to really like the marine flavor, common to all raw seaweeds. All the others that the writer has tasted, except those mentioned above, have a much stronger flavor, which is sometimes slightly bitter or suggests iodin, or, again, it is slightly fishy, so that it would not appeal to the average American palate.

Many of the seaweeds, when cooked in soups, gravies, or with meats or made into jellies, are entirely free from this disagreeable or peculiar flavor. If cooked too long, or too large a quantity is used in the soups or jellies, the flavor is apt to be strong, but if used in smaller quantities it is very delicate and pleasant. The writer has carefully tested a number of species, cooking them in a variety of combinations. They seem to be equally palatable when used either fresh or dried. The bleached seaweeds of course make the best appearing jelly and blancmange, and look best in the soups and stews.

The most attractive and delicately flavored coffee, fruit, or other jellies and blancmange was made by the writer from the four gelatinous limus mentioned above. They were equal in every way to jellies made from the best gelatins in the market, and in some ways seemed superior in flavor. The blancmange could not be distinguished from that made with Irish moss farina or with the whole Irish moss.

No doubt these native limus which occur in large quantities could be collected and bleached on the sand or rocks by the natives, and when dry and clean ground into farina or made into gelatin as good as any in the market. The farina made from limu huna, limu manauea, limu akiaki, and limu pakaeleawaa would be excellent for thickening soups, stews, and gravies or puddings in the same way as tapioca, sago, or Irish moss farina. When once the public became acquainted with these preparations without doubt they would become popular. A careful, experienced manufacturer might, it would seem, start a new industry here in Hawaii or on the California coast by utilizing the tons and tons of edible and gelatinous algæ in making gelatin or glue, such as that made in Japan, or farina, as on the coast of New England. There is no reason why Hawaiian species could not be made into as good gelatin and glue as the Japanese or Ceylon algæ. If scientific methods were used in its preparation, and labor was reasonable, we ought to be able to make our algæ as profitable as that of Japan. The many poor Hawaiians living along the beaches, who have no fertile land to cultivate and are only skilled in fishing, swimming, and rowing, could engage in collecting algæ for such a factory. The women and children could help in this industry and all could stay at home together. They would need no tools and no capital or no training for this work. A few simple instructions about cleaning, drying, and bleaching would be sufficient, for the natives know the haunt of every edible limu. A very cheap mill would do for grind-

$1628-07-6$ 
ing the limu into meal or farina, which would need to be boxed and labeled attractively. The gelatin factory would require more machinery and more capital. It may be that if no factory should be started here our Hawaiians might collect, dry, and bleach their limus and ship them to the coast in bags ready to manufacture, and still make it a profitable industry.

METHODS OF PREPARING JELLIES, BLANCIMANGE, SOUPS, ETC.

Coffee jelly and other similar jellies or gelatin desserts are prepared in the same manner as when ordinary gelatin is used, except that the gelatin must first be extracted from the algæ as described above in gelatin preparations. The clear, strained gelatin is then sweetened and flavored with fruit juice, coffee, ete., and placed in a mold to stiffen. It is then served with sweetened and flavored cream, just as with all gelatin jellies. The amount of dried seaweed needed for a pint of jelly varies from 1 to 4 ounces, depending upon the variety of algæ and the stiffness desired in the jelly. The time of cooking also varies with the algæ, and is from one to two hours.

Blancmange is made just as with Irish moss, by cooking the algæ slowly in sweet milk and then straining through a bag. After it is sweetened it is placed in the mold on ice to cool and served with cream sweetened and flavored to taste.

The same limus used in making gelatin are of course used for jellies, blancmange, and in meats and soups. Limu manauea makes the most delicately flavored desserts, though limu huna, limu akiaki, and limu pakaeleawaa are almost as good. Limu kohu is also a pleasant addition to soups or stews if used sparingly, an ounce or two to a kettleful of soup.

\section{COMPARISON OF HAWAIIAN AND JAPANESE SPECIES OF ECONOMIC ALGBE.}

Though Hawaii is a group of recent volcanic islands in mid-ocean, it has a rather varied marine flora along the coasts. There are a hundred and ten or fifteen different species found on these islands. About seventy of these are used for food by some of the Hawaiians. From forty-five to fifty species are in general use for food by most of the Hawaiians on the different islands where they grow.

Japan, being composed of older continental islands, would naturally be expected to have a richer seaweed flora (and probably it has), but Mr. Smith ${ }^{a}$ reports a much smaller number of edible seaweeds from those islands than we have in Hawaii. He reports but 35 species that are eaten by the Japanese and 10 others valuable for making glue, gelatin, iodin, fertilizers, etc.

$a$ H. M. Smith, Seaweed Industries of Japan. Bul. [U. S.] Bureau of Fisheries, 24 (1904). 
Not all of these 70 seaweeds eaten by the Hawaiians would be agreeable to the palate of the average American. Probably not more than 8 or 10 out of the 70 would be eaten either by the American or the European, and some of these 10 only occur in limited quantity and only in a few localities. There may, of course, be a few seaweeds here in Hawaii that will prove to be valuable for fertilizers, iodin, or gelatin that have not yet been tested, as the Sargassums.

Probably none of our Hawaiian seaweeds occur in such large quantities as those in Japan, since our coast is much less extensive and many of our islands have bold, precipitous coasts, with very deep water coming up close to the shore on one or two sides. Algæ grow most abundantly in the shallower waters near the coast, and hence the more coral reefs and the more extensive shallows the greater variety and quantity of seaweed. It is, of course, more easily collected on shallow rocky coasts or in coves and bays protected by wide coral reefs, while it is always most plentiful on the coral rocks in these shallows. The tougher, more leathery varieties thrive in the more exposed places and find secure anchorage on the black lava rocks or basalt, as well as on the softer vesiculate lava, which is usually covered with algæ of various kinds, different from that growing on the coral.

While Hawaii is within the tropic zone and probably considerably warmer than Japan, yet she has some of the same species of economic algæ that grow on her coasts. Hawaii produces eight or nine species of Gelidium, while one is the same species (Gelidium corneum) which is found so abundantly in Japan and is used in the manufacture of seaweed gelatin. Our species of Gelidium are undoubtedly as gelatinous as the Japanese species, but they are not nearly so plentiful. We also have Gracilaria conferveides and G. coronopifolia, which are very common on the coasts of Japan. Gracilaria coronopifolia is particularly rich in gelatin of the best quality suitable for food, and it also occurs in considerable quantities on all the islands but Hawaii. Our $P$. leucosticta is somewhat similar to the two Porphyras of Japan used in making amanori, but is too rare and too difficult to collect to be of any economic importance here on Hawaii. We also have two edible species of Codium, while Japan has three edible species, but different from ours. Our edible Grateloupia filicina is the same as the one used in Japan, though they have two other edible species of Grateloupia. We have two of the three Japanese species of Enteromorpha, besides three or four more edible species. There are two edible species of Gymnogongrus reported from Japan, and we have the same number here, though different species. Of our three edible Ulvas, one is the same, one a variety, and the other is a nearly related species to those found in Japan. We have three or four species of edible 
Sargassum, while Japan has only one species of Sargassum, which is used for making iodin.

The Japanese waters are rich in kelps, laminarias, alaria, ecklonia, and other genera of colder waters, but Hawaii has none, nor has she any Chondrus or Gloiopeltis, both of which thrive best in the North Pacific along the coasts of Japan and the United States. The kombu and wakome preparations of Japan are all made from Laminaria and related genera in the kelp group.

It will be seen from the above comparison of genera and species that there is some resemblance between the seaweeds of Japan and Hawaii. Our waters being warmer we naturally have more tropical species and no kelps. Yet quite a number of genera and several species are exactly the same. 'This would indicate either that these species flourish under widely different temperatures and conditions, or that our water is not so much warmer as the difference of latitude would suggest. Japan has the volcanic rock and the black lava just as we have here, but probably no coral reefs for the algæ.

\section{POSSIBILITY OF CULTIVATING NATIVE, JAPANESE, JAVA, OR CEYLON ALG更 IN FAVORABLE LOCALITIES ON THE HAWAIIAN OR AMERICAN COAST.}

As previously mentioned, the Hawaiians have attempted a rude method of cultivating and transplanting their favorite algæ from one island to another. In moving from island to island the chiefs carried their favorite limu pakaeleawaa from Hawaii to Oahu and to Molokai. It was transplanted carefully along protected beaches or on the inner side of old fish ponds, where it still thrives. The writer found this alga growing only in one place on Molokai, and was told by the natives that it had been planted by a chief in his fish pond. In the same manner it has been planted on Oahu in several places and is thriving. Limu is weeded and cared for on the island of Kauai in order to increase the quantity and quality.

If these crude methods of culture succeed and the natives can establish an alga in a new place successfully, why should not more careful scientific means be very successful if the most desirable varieties of Hawaiian algæ were planted in the most favorable localities on each island?

Perhaps some of the most valuable Japanese algæ could be introduced on the coast of Hawaii and be successfully established. It is possible, too, that certain species of algæ growing on the coasts of Ceylon and Java could also be just as readily transplanted to our islands, because the temperature of the sea is about the same, especially off the coast of Hawaii. Much of the agar-agar of commerce is prepared from the gelatin obtained from seaweeds from Java and Ceylon. This very important requirement of every bacteriological laboratory 
might be produced here in Hawaii just as well as in Japan or the East Indies, providing, of course, that our own algæ proves as rich in gelatin or if the Japanese and East Indian seaweeds can be successfully introduced and cultivated here. Some experiments along this line might be very valuable, and they would certainly be very interesting. There are many of our rocks and reefs quite thinly covered or nearly barren of seaweeds, and these might be favorable places to establish new varieties, either from other islands or from Japan and the East Indies.

\section{GENERAL SUMIMARY OF THE POSSIBILITIES OF THE SEAWEED INDUSTRY.}

If the seaweed industry of Japan is the source of an annual income of $\$ 2,000,000$, it seems possible that our edible Hawaiian algæ might be available for building up a similar industry of considerable value. The coast line of Hawaii is much less extensive and the amount of seaweed of course very much less, yet there is enough material to supply large factories for making gelatin, glue, farina, or other products. If in addition to the present natural sources of seaweed new localities be successfully planted, either with native, Japanese, or other valuable foreign varieties, a still larger supply of algæ would be available for manufacturing. It would of course take some capital, business judgment, and knowledge of the seaweeds and their manufacture to successfully establish such an industry here or on the coast of the United States. If it is so profitable in Japan, why should it not be profitable here, if properly handled? There are enough Japanese laborers here who know all the methods of preparing algæ to suit the Oriental palate, and these could be employed to do that part of the work in the factory, while the Hawaiians, who love the water and are such expert swimmers and boatmen, could be employed to collect the crude algæ from the sea and bring it to the factory. This would bring employment to the untrained Hawaiians and furnish them with a means of living while they remained at home. The women and children could also help with this work of gathering and drying or bleaching the seaweed for the manufacturer. Some industry of this kind only will bring relief to the mass of the Hawaiians, who are unskilled and undisciplined, so are unable to compete with either the Orientals or Europeans in any branch of labor. The Japanese have driven them out of fishing, at which they are most skillful, because they will not be strenuous or regular enough to furnish the market with fish. Small farming is not practicable for the Hawaiian under present conditions, because it requires more capital, skill, and intelligence than the present Hawaiian possesses. Perhaps in two or three more generations the Hawaiian will acquire the skill, the capital, and the disposition to enter agricultural pursuits gladly. In the meantime poverty and distress are the lot of a large class of landless Hawaiians 
living along our coast. If the tons of algæ wasting on our shores could be utilized for gelatin, glue, farina, etc., it would bring some relief to this class, as well as add to the general wealth and prosperity of these islands and to the United States.

The gelatins and glues imported from Japan could be made in the United States just as cheaply, perhaps. Modern methods scientifically applied and machinery would reduce the manufacturing expenses to a minimum. A new source of food for our American people here and in the United States would add also to our national wealth. Further experiments and analyses should be made by the Government to test the nutritive value of our algæ and to find the best methods of securing the greatest amount of gelatin from each variety. Enough has already been done to suggest the future value of our economic algæ if properly utilized.

\section{List of edible alga of Hawaiian Islands.}

Scientific names.

Ahnfeldtia concinna J. Agh...

Asparagopsis sanfordiana Harv .......... Limu kohu, limu lipaakai, $b$ limu lipehu, limu koko.

Amansia glomerata $\mathrm{Ag}$ Limu lipepeiao, ${ }^{c}$ or limu pepeiao.

Centroceras clavulatum (Agh.), Mont....... Limu huluilio, limu hulu, or limu hulu wawae-iole.

Chxtomorpha antennina (Bory.), Kuetz .... Limu huluilio, d limu ilio, or limu manu. Champia compressa, Harv ................ Limu oolu.

Chnoospora fastigata pacifica, J. Ag. . . . . . . . Limu wawahiwaa, or limu kaupau.

Chondria tenuissima intermedia ............. Limu oolu.

Chylocladia rigens? .................. Limu akuila, or limu kihe.

Cladophora nitida, Kuetz................. Limu huluilio.

Codium muelleri, Kuetzing............. Limu aallaula, e limu wawaeiole, or limu wawaimoa.

Codium adhærens (Cabr.), Agh ............ Limu aalaula.

Codium tomentosum (Huds.), Stackh........

Dictyota acutiloba distorta. . . . . . . . . . . . . Limu alani, $f$ or false lipoa.

Dictyota dichotoma. Do.

Ectocarpus indicus? .................... Limu akakkoa, or limu huluilio.

Ectocarpus sp.?. Do.

Enteromorpha flexuosa (Wulf.), Ag......... Limu eleele, or limu pipilani. g

$a$ Many of the limus have different local names, or each island or adjoining islands has its own name. Limu eleau is used on Maui only.

${ }^{b}$ This limu is usually called limu kohu, except on Maui, Molokai, and Kauai. It is often called limu lipaakai and sometimes limu lipehu. Limu koko is a corruption of kohu. ,

${ }^{c}$ Different forms of the same name on Hawaii, not widely used, local.

$a$ Not widely used; only local on several islands, chiefly on Hawaii and Maui, and this name is applied to several species slightly resembling each other. It means dog's hair.

$e$ The last two names found in use in some places on Hawaii, not common.

$f$ This is generally called limu alani, but sometimes called false limu lipoa, which it resembles slightly. It is eaten but seldom, as it is bitter.

$g$ On Maui it is sometimes called limu pipilani. Limu eleele is the name for most all the Enteromorphas of these islands. 
Scientific names.

Enteromorpha hopkirkii

Enteromorpha linza (L.), J. Ag............

Enteromorpha plumosa, Kuetzing ..........

Enteromorpha prolifera tubulosa, Kg........

Enteromorpha prolifera (Muell.), J. Ag.....

Gelidium attenuatum?.

Gelidium corneum var.? (Huds.) Lamour...

Gelidium filicinum?

Gelidium latifolium? Born

Gelidium micropterum?

Gelidium pulvinatum?

Gelidium pusillum?

Gelidium sp.?

Gracilaria coronopifolia, J. Ag.............

Grateloupia filicina (Wulf.), Agh......... Limu pakaeleawaa or limu huluhuluwaena.

Griffithsia sp.?.

L. moopuna, limu ka-lipoa, $c$ or limu aupupu.

Gymnogongrus vermicularis americana, J. $\begin{aligned} & \text { Limu uaualoli. } d \\ & \text { Limu ekahaekaha. }\end{aligned}$

Ag.

Gymnogongrus diciplinalis (Bory.), J. Ag..

Limu eleele, or limu pipilani. $a$

Do.

Do.

Limu loloa.

Do.

Limu loloa or limu ekahakaha.

Limu loloa.

Do. $b$

Do.

Do.

Limu kekuwelu or limu kuwelu.

Limu manauea.

Limu koeleele or koele.

Limu awikiwiki.
Enteromorpha intestinalis (L.), Link........

Limu nei.

Limu lipoa.

Do.

Haliseris plagiogramma, Mont .............

Haiymenia formosa .................... Limu lepeahina (very rare).

Hydrodictyon 'reticulatum (Linn.) Lagerh... Limu palawai.

Hypnea nidifica, J. Ag.................. Limu huna.

Hypnea armata ........................... Do.

Laurencia papillosa (Forst.), Grev......... . Limu maneoneo $f$ or limu lipeepee.

Laurencia pinnatifida (Gmel.), Lamour .... L. maneoneo, limu olipeepee, or limu lipee.

Laurencia pinnatifida osmunda.

Laurencia perforata....................

Laurencia obtusata .....................

Laurencia virgata (Ag.), J. Ag .............

Laurencia sp.? ...................... Limu maneoneo or limu lipuupuu.

Liagora decussata . . . . . . . . . . . . . . . . . . Limu puaki.

Nais major, All ..................... Limu kala-wai.g

$a$ On Maui it is sometimes called limu pipilani. Limu eleele is the name for most all the Enteromorphas of these islands.

$b$ This name is in very general use on Hawaii and Maui, but both names are common on Oahu.

c This alga is considered a delicacy on Maui and southern Hawaii, but is very scarce and spoils very soon, so have not been able to secure enough to identify the species.

$d$ This limu is usually called limu uaualoli, but the other names are used in certain localities.

$e$ This is very rare, only washed ashore occasionally, but resembles the other limu lipoa, hence the name.

$f$ The several species of Laurencia are generally called limu maneoneo, if coarse and short, and limu lipeepee if finer and longer. Limu lipee is an abbreviation, while limu lipuupuu has only local use in places on Hawaii and Maui.

$g$ This is not an alga, but a flowering plant sold in the market as a limu, probably because it grows in fresh water and resembles the common limu kala from the sea. 
Nitophyllum? ....................... Limu haula. ${ }^{a}$

Pithophora affinis? Nordst............... Limu palawai $b$ or limu lipalawai.

Pithophora polymorpha.................. Do.

Polyopes? ............................ Limu luau. ${ }^{c}$

Polysiphonia mollis .................... Limu pualu $d$ or limu hawane.

Porphyra leucosticta, Thurst.............. Limu luau or limu lipahee.e

Pterocladia capillacea (Gmel.), Bornet ..... Limu loloa. $f$

Sargassum echinocarpum, J. Ag............ Limu kala.

Sargassum cymosum, Ag................. Do.

Sargassum polyphyllum. J. Ag............. Do. Do.

Spiridia spinella...................... Limu hulupuaa. $g$

Spirogyra sp. (probably several) $h$.......... Limu palawai, limu nehe, and lịmu polao.

Stigeoclonium amøenum, $\mathrm{Kg}$............... Limu huluilio. ${ }^{i}$

Stigeoclonium sp? ...................... Limu palawai or limu lipalawaie

Strebdocladia? ........................ Limu hawane. $h$

Ulva fasciata, $j$ Delile .................... Limu pahapaha or limu palahaloha.

Ulva lactuca rigida (Agh.) Le Jolis ......... Limu lipahapaha.

Ulva lactuca lacinata (Wulf. ) J. Ag ......... Limu lipalahalaha, limu pakaea.

Valonia utricularis.................... Limu lipuupuu.

$a$ Very rare, only one small specimen obtained from a native on Maui.

$b$ Most all the edible green fresh-water algæ are called lipalawai or polawaie, and there are perhaps a half dozen species in the mountain streams that are known by these names.

${ }^{c}$ A single small specimen sent by native on Maui, similar to Porphyra.

$d$ Used by but few Hawaiians for food; not popular.

$e$ Reported only from two islands and scarce; called limu luau on Kauai and limu lipahu on Hawaii.

$f$ This species often called limu loloa on Maui and Kauai.

$g$ Not in general use, but eaten in the southern part of Hawaii.

$h$ Imperfect and immature specimens, so could not be positively identified.

$i$ This grows in brackish water pools by the sea and is eaten by only a few Hawaiians.

$j$ These three species seem to be indistinguishable by the natives, and the different islands and localities have various forms of the name, but limu pakaea is only in use on Hawaii. 